\title{
多層地盤中の多段アンカー付き抑え杭の特性について \\ On the Characteristic Features of the Cantilever Type Pile (Osaegui) with Anchors in the Lateral Layers
}

\author{
小島 義 孝* \\ 山本哲三** \\ 速 水博 秀*** \\ Yoshitak KoJIma Tetsuzou Yamamoto Hirohide HAYAMIZU
}

\begin{abstract}
Recently steel pile work has been developed as an effective countermeasure against landslides.

We introduce a general method of calculating the deflection, angle of deflection, bending moment, shearing force and anchor forces of the pile with anchors in the lateral layers under arbitary load conditions for the design of the cantilever type for landslide prevention.

We analize the characteristics of the pile under various conditions using a personal computer.
\end{abstract}

キーワード：地すベり，杭，アンカー設計計算

\section{1. はじめに}

近年，地すべり抑止工や山留工などでアンカー付きの 杭工あるいは親杭（横矢板）アンカー工などが実施され ることが多い。しかしながら，実際にこれらの工法を設 計する場合，杭とアンカーの負担力の割合を決定する簡 便で合理的な方法が確立されているとは言い難いのが現 状である。杭を主体にするかアンカーを主体にするかで 異なるが，負担すべき抑止力や土圧はいずれか一方に受 持たせる場合が多いよらである。ここでは，多層地盤中 の抑え杭（地すべり推力を片持梁的に受け持つ杭）にア ンカーを多数取り付けたときの杭のたわみ，たわ 又角, 曲げモーメント，せん断力を決定する $1 つ$ の一般的方法を述べる。またその結果をパソコン 上でプログラミングして，抑え杭に対するアンカ 一の段数, 地盤の層数, 外力の分布形態の力学的 影響を検討した。

\section{2. 計算手法}

図-1に示す計算モデルに基づいて力のつりあい 方程式をたてると次のよらになる。すなわち，移 動層の $i$ 番目の区間に対して,

$$
E I \frac{d^{4} y_{i}}{d x_{i}{ }^{4}}=0 \quad(i=1 \sim m)
$$

不動層の $i$ 番目の地層に対しては

$$
E I \frac{d^{4} y_{i}}{d x_{i}{ }^{4}}+E_{S} y_{i}=0 \quad(i=1 \sim n)
$$

境界条件は，次のと括りである。

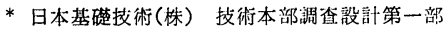

$$
\begin{aligned}
& \text { ** " " 北陸支店調睢設䛅部 } \\
& \text { *** " }
\end{aligned}
$$

$$
\begin{array}{r}
x=-L_{E} \text { で } y^{\prime \prime}=0, y^{\prime \prime \prime}=0 \\
x=-l_{i} \text { で } y_{i-1}=y_{i}, y^{\prime}{ }_{i-1}=y_{i^{\prime}}, \quad y^{\prime \prime}{ }_{i-1}=y_{i}{ }^{\prime \prime}, \\
y_{i-1}{ }^{\prime \prime \prime}=\frac{H_{i}}{E I}+y_{i^{\prime \prime \prime}}(i=1 \sim m) \\
x=L_{R} \text { で } y=0, y^{\prime}=0 \text { または } y^{\prime \prime}=0, y^{\prime \prime \prime}=0
\end{array}
$$

(1)式および(2)式の一般解はそれぞれ次の(4)，(5)式で表 わされる。

$$
\begin{aligned}
& y_{i}=a_{i} x^{3}+b_{i} x^{2}+c_{i} x+d^{2} \\
& y_{i}{ }^{\prime}=3 a_{i} x^{2}+2 b_{i} x+c_{i}, \quad \theta_{i}=y_{i}{ }^{\prime} \\
& y_{i^{\prime \prime}}=6 a_{i} x+2 b_{i}, \quad M_{i}=-E I y_{i}{ }^{\prime \prime}
\end{aligned}
$$

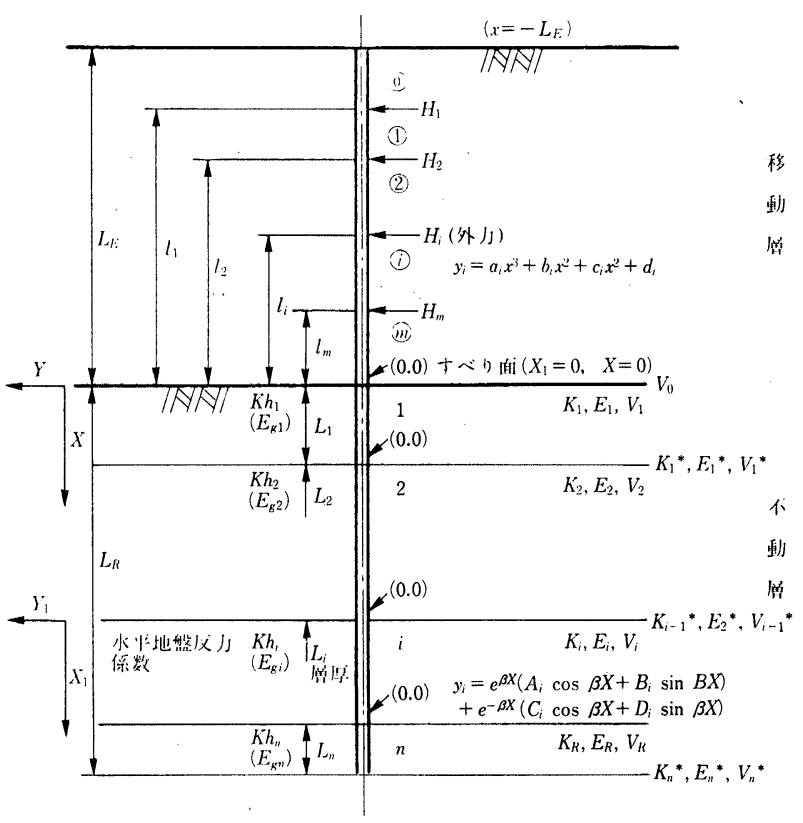

図-1 計算モデル 


$$
\begin{aligned}
& y_{i}{ }^{\prime \prime \prime}=6 a_{i}, \quad S_{i}=-E I y_{i}^{\prime \prime \prime} \\
& (i=1 \sim m) \\
& \left(\begin{array}{c}
y_{i} \\
\theta_{i} \\
M_{i} / E I \\
S_{i} / E I
\end{array}\right)=\left\{\begin{array}{l}
F_{1}\left(\beta_{i} x_{i}\right), \quad F_{3}\left(\beta_{i} x_{i}\right), \\
\beta_{i} F_{2}\left(\beta_{i} x_{i}\right), \quad \beta_{i} F_{4}\left(\beta_{i} x_{i}\right), \\
2 \beta_{i}{ }^{2} F_{3}\left(\beta_{i} x_{i}\right), \quad-2 \beta_{i}{ }^{2} F_{1}\left(\beta_{i} x_{i}\right), \\
2 \beta_{i}{ }^{3} F_{4}\left(\beta_{i} x_{i}\right), \quad-2 \beta_{i}{ }^{3} F_{2}\left(\beta_{i} x_{i}\right),
\end{array}\right. \\
& G_{1}\left(\beta_{i} x_{i}\right), G_{3}\left(\beta_{i} x_{i}\right) \\
& -\beta_{i} G_{2}\left(\beta_{i} x_{i}\right), \quad \beta_{i} G_{4}\left(\beta_{i} x_{i}\right) \\
& -2 \beta_{i}{ }^{2} G_{3}\left(\beta_{i} x_{i}\right), 2 \beta i^{2} G_{1}\left(\beta_{i} x_{i}\right) \\
& -2 \beta_{i}^{3} G_{4}\left(\beta_{i} x_{i}\right), \quad-2 \beta_{i}^{3} G_{2}\left(\beta_{i} x_{i}\right) \\
& (i=1 \sim n)
\end{aligned}
$$

ただし $F_{1}\left(\beta_{i} x_{i}\right)=e^{\beta i x_{i}} \cos \beta_{i} x_{i}$

$$
\begin{aligned}
& G_{1}\left(\beta_{i} x_{i}\right)=e^{-\beta_{i} x_{i}} \cos \beta_{i} x_{i} \\
& F_{2}\left(\beta_{i} x_{i}\right)=e^{\beta i x_{i}}\left(\cos \beta_{i} x_{i}-\sin \beta_{i} x_{i}\right) \\
& G_{2}\left(\beta_{i} x_{i}\right)=e^{-\beta_{i} x_{i}}\left(\cos \beta_{i} x_{i}+\sin \beta_{i} x_{i}\right) \\
& F_{3}\left(\beta_{i} x_{i}\right)=e^{\beta i x_{i}} \sin \beta_{i} x_{i} \\
& G_{3}\left(\beta_{i} x_{i}\right)=e^{-\beta_{i} x_{i}} \sin \beta_{i} x_{i} \\
& F_{4}\left(\beta_{i} x_{i}\right)=e^{\beta i x_{i}}\left(\cos \beta_{i} x_{i}+\sin \beta_{i} x_{i}\right) \\
& G_{4}\left(\beta_{i} x_{i}\right)=e^{-\beta_{i} x_{i}}\left(\cos \beta_{i} x_{i}-\sin \beta_{i} x_{i}\right)
\end{aligned}
$$

(4)式，(5)式の係数 $a_{i}, b_{i}, c_{i}, d_{i}, A_{i}, B_{i}, C_{i}, D_{i}$ を定めることができれば，これらの式を用いて，たわみ $y_{i}$, たわみ角 $\theta_{i}$, 曲げモーメント $M_{i}$, せん断力 $S_{i}$ を 杭の各位置で計算することができる。なお， $a_{i} ， b_{i}$ は 移動層の外力条件だで定まり, 次式で与えられる。

$$
\begin{gathered}
a_{i}=-\frac{\sum_{1}^{i} H_{k}}{6 E I} . \\
a_{i}=-\frac{\sum_{1}^{i} H_{k} l_{k}}{2 E I}
\end{gathered}
$$

ここで, $H_{k}$ は上から $k$ 番目の外力で, すべり面から $l_{k}$ の距離に作用する。

一方， $c_{i}, d_{i}$ は, 移動層の外力条件だけでは定まら ず, 杭の先端条件 $(y=0, \theta=0$ または $M=0, S=0$ 等) が決ってはじめて定めることができる。杭の先端条件が 決まると,すべり面上での連続条件により, 移動層の最 下㬝の $c_{m}, d_{m}$ を定めることができる。 $c_{m}, d_{m}$ が求 まると次の(8)式，(9) 式を用いて， $c_{i}, d_{i}$ を定めるこ とができる(詳細は後述する)。

$$
\begin{aligned}
& c_{i-1}=\frac{1}{2} \frac{H_{i}}{E I} l_{i}{ }^{2}+c_{i} \\
& d_{i-1}=\frac{1}{6} \frac{H_{i}}{E I} l_{i}{ }^{3}+d_{i}
\end{aligned}
$$

不動層の $i$ 番目の層内の係数 $A_{i}, B_{i}, C_{i}, D_{i}$ は $i-$ 1 番目の㬝との境界上でのたわみ，たわみ角，曲モーメ ント, せん断力の值 $y^{*_{i-1},} \theta^{*_{i-1}}, M^{*_{i-1}}, S^{*_{i-1}}$ によ つて表わすことができる。ここで，すべり面での $y_{0} *$, $O_{0}{ }^{*}, M_{0}{ }^{*}, S_{0}{ }^{*}$ の值 (以後, すべり面での值ではアスタ
リスク*を省略する。）は後述の（16）式で与えられる。 これから， $i$ 番目の層内の $y_{i}, \theta_{i}, M_{i}, S_{i}$ を求めるこ とができる。その関係式を(10)式に示す1)。

$$
\begin{aligned}
& \left\{\begin{array}{c}
y_{i} \\
\theta_{i} \\
M_{i} \\
S_{i}
\end{array}\right\}= \begin{cases}z_{1}\left(\beta_{i} x_{i}\right) & \frac{1}{\beta_{i}} z_{2}\left(\beta_{i} x_{i}\right) \\
-4 \beta_{i} z_{4}\left(\beta_{i} x_{i}\right) & z_{1}\left(\beta_{i} x_{i}\right) \\
4 E I \beta_{i} z_{3}\left(\beta_{i} x_{i}\right) & 4 E I \beta_{i} z_{4}\left(\beta_{i} x_{i}\right) \\
4 E I \beta_{i}{ }^{3} z_{2}\left(\beta_{i} x_{i}\right) & 4 E I \beta_{i} z_{3}\left(\beta_{i} x_{i}\right)\end{cases} \\
& \left.\begin{array}{ll}
-\frac{1}{E I \beta_{i}{ }^{2}} z_{3}\left(\beta_{i} x_{i}\right) & -\frac{1}{E I \beta_{i}{ }^{3}} z_{4}\left(\beta_{i} x_{i}\right) \\
-\frac{1}{E I \beta_{i}{ }^{2}} z_{2}\left(\beta_{i} x_{i}\right) & -\frac{1}{E I \beta_{i}{ }^{2}} z_{3}\left(\beta_{i} x_{i}\right) \\
z_{1}\left(\beta_{i} x_{i}\right) & \frac{1}{\beta_{i}} z_{2}\left(\beta_{i} x_{i}\right) \\
-4 \beta_{i} z_{4}\left(\beta_{i} x_{i}\right) & z_{1}\left(\beta_{i} x_{i}\right)
\end{array}\right\}\left\{\begin{array}{c}
y_{i-1} * \\
\theta_{i-1} * \\
M_{i-1} * \\
S_{i-1} *
\end{array}\right\}
\end{aligned}
$$

ここで,

$z_{1}(\beta x)=\cosh \beta x \cdot \cos \beta x$

$z_{2}(\beta x)=\frac{1}{2}(\cosh \beta x \cdot \sin \beta x+\sinh \beta x \cdot \cos \beta x)$

$z_{3}(\beta x)=\frac{1}{2} \sinh \beta x \cdot \sin \beta x$

$z_{4}(\beta x)=\frac{1}{4}(\cosh \beta x \cdot \sin \beta x-\sinh \beta x \cdot \cos \beta x)$

$\cosh \beta x \frac{1}{2}\left(e^{\beta x}+e^{-\beta x}\right)$

$\sinh \beta x=\frac{1}{2}\left(e^{\beta x}-e^{-\beta x}\right)$

(10)式の右辺第 1 項のマトリックスを $E_{i}$ ，第 2 項の ベクトルを $V^{*}{ }_{i-1}$, 左辺のベクトルを $V_{i}$ とすると(10) 式は次のように書ける。

$$
\begin{aligned}
V_{i}=E_{i} \cdot V_{i-1} * & =E_{i} \cdot E_{i-1} * \ldots E_{1} * \cdot E_{2} * \cdot V_{0} \\
& =E_{i} \cdot K_{i-1} * \cdot V_{0}=K_{i} V_{0} \ldots
\end{aligned}
$$

ただし， $K_{i-1} *=E_{i-1} * \cdot E_{i-2} \cdots \cdots E_{2} \cdot E_{1} *$ であり,$E_{i-1} *$, $V_{i-1} *, K_{i-1} *$ は $E_{i-1}, V_{i-1}, K_{i-1}$ の $x_{i}$ の代わりに $L_{i}$ を代入したものである。

杭の先端では, 次式が成立する。

$$
V_{n} *=K_{n} * V_{0}
$$

ただし，

$$
\begin{aligned}
& V_{n}^{*}=\left(y_{n}, \theta_{n}, n M_{n}, S_{n}\right)^{T}, \quad V_{0}=\left(y_{0}, \theta_{0}, M_{0}, S_{0}\right)^{T} \\
& K_{n} *=\left(\begin{array}{llll}
a_{11} * & a_{12} * & a_{13} * & a_{14} * \\
a_{21} * & a_{22} * & a_{23} * & a_{24} * \\
a_{31} * & a_{32} * & a_{33} * & a_{34} * \\
a_{41} * & a_{42} * & a_{43} * & a_{44} *
\end{array}\right)
\end{aligned}
$$

もし, 杭の先端で $y_{n}=0, \theta_{n}=0$ が成立すると(12)式 から, 次の関係が得られる。

$$
\left.\begin{array}{l}
a_{11} * y_{0}+a_{12} * \theta_{0}+a_{13} * M_{0}+a_{14} * S_{0}=0 \\
a_{21} * y_{0}+a_{22} * \theta_{0}+a_{23} * M_{0}+a_{24} * S_{0}=0
\end{array}\right\}
$$


また，杭の先端で $M_{n}=0, S_{n}=0$ が成立するならば， 同様にして, 次の関係を得る。

$$
\left.\begin{array}{l}
a_{31} * y_{0}+a_{32} * \theta_{0}+a_{33} * M_{0}+a_{34} * S_{0}=0 \\
a_{41} * y^{0}+a_{42} * \theta_{0}+a_{43} * M_{0}+a_{44} * S_{0}=0
\end{array}\right\}
$$

一方，すべり面に执いては， $y, \theta, M, S$ の連続条件 により次の関係式を得る。

$$
\left.\begin{array}{l}
y_{0}=y_{m}=d_{m} \\
\theta_{0}=\theta_{m}=c_{m} \\
M_{0}=M_{m}=-2 b_{m} E I \\
S_{0}=S_{m}=-6 a_{m} E I
\end{array}\right\}
$$

$y_{n}=0, \theta_{n}=0$ が成立するならば(14)式及び(16)式か

5 , 次式を得る。

$$
\begin{aligned}
& c_{m}=\left[\left\{2\left(a_{13 *} a_{21} *-a_{23} * a_{11} *\right) b_{m}+6\left(a_{14} * a_{21} *\right.\right.\right. \\
&\left.\left.\left.-a_{24} * a_{11} *\right) a_{m}\right\} /\left(a_{12} * a_{21} *-a_{11} * a_{22} *\right)\right] E I \\
& \ldots \ldots \ldots \ldots \\
& d_{m}=\left[\left\{2\left(a_{13} * a_{22} *-a_{23} * a_{12} *\right) b_{m}+6\left(a_{14} * a_{22} *\right.\right.\right. \\
&\left.\left.\left.-a_{24} * a_{12} *\right) a_{m}\right\} /\left(a_{12} * a_{21} *-a_{11} * a_{22} *\right)\right] E I
\end{aligned}
$$

また, $M_{n}=0, S_{n}=0$ が成立する場合は, 次式を得る。

$$
\begin{aligned}
& c_{m}=\left[\left\{-2\left(a_{33} * a_{41} *-a_{43} * a_{31} *\right) b_{m}+6\left(a_{34} * a_{41} *\right.\right.\right. \\
&\left.\left.\left.-a_{44} * a_{31} *\right) a_{m}\right\} /\left(a_{31} * a_{42} *-a_{41} * a_{32} *\right)\right] E I \\
& \ldots \ldots \ldots \ldots \\
& d_{m}=\left[\left\{2\left(a_{33} * a_{42} *-a_{43} * a_{32} *\right) b_{m}+6\left(a_{34} * a_{42} *\right.\right.\right. \\
&\left.\left.\left.-a_{44} * a_{32} *\right) a_{m}\right\} /\left(a_{31} * a_{42} *-a_{41} * a_{32} *\right)\right] E I
\end{aligned}
$$

(17) (20)式で $c_{m}, d_{m}$ が求まると，(8)，(9) 式を 用いて, すべての $c_{i}, d_{i}$ を求めることができ，(4)式 より移動層部の $y, \theta, M, S$ を計算することができる。 不動㬝部の $y, \theta, M, S$ は(11)式を用いて計算するこ とができる。

次に, 多段アンカーの設計アンカー力を求める。設計 アンカーカの水平成分はアンカーを取り付ける位置で, たわみを与えたとき，そのたわみを維持するのに必要な 外力として求める。たわみは0でなくともよいが 0 とし た方が仕上りが美しくなり，自然であるので，設計アン カー力（の水平成分）としてはたわみが０となるよらな 外力として求めるとよい。実際の設計アンカー力は，上 に述ベた方法によって求められた設計アンカーカの水平 成分とアンカー打設角から求める。

いま，図-2のように不明の外力が $k$ 個あるとし，それ を $X_{j i}(i=1 \sim k)$ で表わす。このとき，次の $k$ 個の関係 式を得る。

$$
\begin{aligned}
& a_{j i}{ }^{\prime} l_{j i^{3}}-b_{j i}{ }^{\prime} l_{j i}{ }^{2}+c_{m}{ }^{\prime} l_{j i}+f_{j i} l_{j i}-d_{m}{ }^{\prime}-e_{j i} \\
& =\left(\frac{l_{j i^{3}}}{6 E I}-\frac{l_{j 1} l_{j i^{2}}}{2 E I}+\phi_{3} l_{j 1} l_{j i}+\phi_{4} l_{j i}-\phi_{1} l_{j 1}-\phi_{2}\right) X_{j 1} \\
& +\cdots \ldots \ldots \ldots \ldots \ldots \ldots \ldots \ldots \ldots \\
& +\left(-\frac{l_{j(i+1)}{ }^{3}}{6 E I}+\frac{l_{j i} l_{j(i+1)}}{2 E I}+\phi_{3} l_{j i} l_{j(i+1)}+\phi_{4} l_{j(i+1)}\right.
\end{aligned}
$$

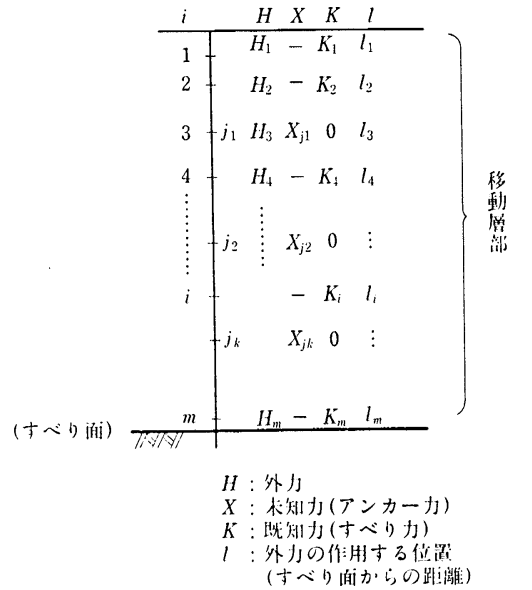

图-2 絈知力（とすべり力）と末知力（アンカー力）の関係

$$
\begin{aligned}
& \left.\cdots \phi_{1} l_{j(i+1)}-\phi_{2}\right) X_{j(i+1)}+\cdots \ldots \ldots \ldots \ldots \ldots \ldots \ldots \ldots \ldots \ldots \ldots \ldots \ldots \ldots \\
& +\left(-\frac{l_{j k}^{3}}{6 E I}+\frac{l_{j i} l_{j k^{2}}}{2 E I}+\phi_{3} l_{j i} l_{j k}+\phi_{4} l_{j k}\right. \\
& \left.-\phi_{1} l_{j k}-\phi_{2}\right) X_{j k}
\end{aligned}
$$

ここで,

$a_{i}{ }^{\prime}=-\frac{1}{6 E I} \sum_{i=1}^{i} K_{i}\left(K_{i}\right.$ は地すべり力 (既知) $)$

$$
\begin{aligned}
& b_{i}{ }^{\prime}=-\frac{1}{2 E I} \sum_{i=1}^{i} K_{i} l_{i} \\
& d_{m^{\prime}}=\left(2 b_{m^{\prime}} \phi_{1}+6 a_{m^{\prime}} \phi_{2}\right) \\
& e_{i}=-\frac{1}{6 E I} \sum_{i=i+1}^{m} K_{i} l_{i}{ }^{3} \\
& c_{m^{\prime}}=\left(2 b_{m^{\prime}} \phi_{3}+6 a_{\left.m^{\prime} \phi_{4}\right)}\right. \\
& f_{i}=-\frac{1}{2 E I} \sum_{i=i+1}^{m} K_{i} l_{i^{2}} \\
&\left(M_{n}=0, S_{n}=0 \text { の場合 }\right) \\
& \phi_{1}=\frac{a_{33} * a_{42} *-a_{43} * a_{32} *}{a_{31} * a_{42} *-a_{41} * a_{32} *}, \quad \phi_{2}=\frac{a_{34} * a_{42} *-a_{44} * a_{32} *}{a_{31} * a_{42} *-a_{41} * a_{32} *} \\
& \phi_{3}=\frac{a_{43} * a_{41} *-a_{42} * a_{31} *}{a_{32} * a_{41} *-a_{31} * a_{42} *}, \quad \phi_{4}=\frac{a_{34} * a_{41} *-a_{44} * a_{31} *}{a_{32} * a_{41} *-a_{31} * a_{42} *} \\
&\left(y_{n}=0, \theta_{n}=0\right. \text { の場合) } \\
& \phi_{1}=\frac{a_{13} * a_{22} *-a_{23} * a_{12} *}{a_{11} * a_{22} *-a_{21} * a_{12} *}, \quad \phi_{2}=\frac{a_{14} * a_{22} *-a_{24} * a_{12} *}{a_{11} * a_{22} *-a_{21} * a_{12} *} \\
& \phi_{3}=\frac{a_{13} * a_{21} *-a_{23} * a_{11} *}{a_{2} * a_{21} *-a_{11} * a_{22} *}, \quad \phi_{4}=\frac{a_{14} * a_{21} *-a_{24} * a_{11} *}{a_{12} * a_{21} *-a_{11} * a_{22} *}
\end{aligned}
$$

\section{3. 計算結果}

上に述ベた解析結果をパソコン用にプログラミングし た。用いた言語はベーシック（BASIC）である。流れ図 を図-3に示す。

杭として, $450.0 \times 28.0 \mathrm{~mm}$ の厚肉遠心力鋳鋼管を用 
い, 48. 3tf の地すべり力が水平に作用するものとして, 地すべり力の分布形態, アンカーの段数, 根入れ地盤の 周数を変化させて，定量的な検討を行った。図-4k共通 する計算条件を示す。検討の方法は, 地層が 1 層でアン, カーなしの所謂「抑㫕杭」の杭の状態（図5-1, 表-1の CASE 1) を基準にし，次の (1)，(2)，(3)のように条件を 変化させたとき，杭のたわみ，たわみ角，曲モーメント せん断力がどのように変わるかを調べた。

(1) 外力の合計を一定 (48.3tf) とし, 分布形態を変 化させる。

(2) アンカーの段数を增す。

(3) 根入れ地盤の地層数を増す。

以下の表-1及び図-5.1〜 5.4亿計算結果をまとめた。な お，計算には富士通のパソコン FMR-70HX 2 (CPU; 32 ビット，クロック数; 20MHZ) 及び FMR-60FD (CPU; 16ビット, クロック数 12MHZ) を用い, 言語は MSDOS 上の F-BASIC $86 \mathrm{HG}$ という BASICを使用した。

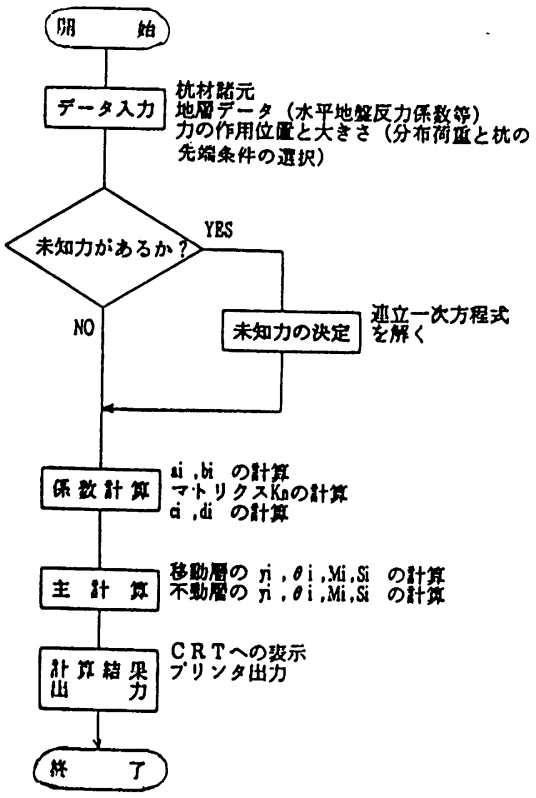

図-3 流れ図

\begin{tabular}{|c|c|c|}
\hline ナべカJ & & $\Sigma \mathrm{H}=48.3 \mathrm{tf}$ \\
\hline 沫端生作 & & $M=0, S=0$ \\
\hline 秒届の可さ $9.00 \mathrm{~m}$ & 不怔成 & 居の原さ $13.50 \mathrm{~m}$ \\
\hline 比の将性俰数 $\mathrm{E}$ & & $2.10 \mathrm{E}+07 \mathrm{tf} / \mathrm{m}^{2}$ \\
\hline 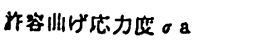 & & $2000 \mathrm{E}+04 \mathrm{t} f / \mathrm{m}^{2}$ \\
\hline 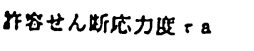 & & $2700 \mathrm{E}+04 \mathrm{t} f / \mathrm{m}^{2}$ \\
\hline $450.0 \mathrm{~mm}$ & 肉车 & $28.0 \mathrm{~mm}$ \\
\hline 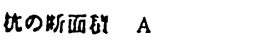 & & $3.7120 \mathrm{E}-02 \mathrm{~m}^{2}$ \\
\hline 邯の所而 2 次モーメント & 18 & $8.2990 \mathrm{E}-04 \mathrm{~m}^{4}$ \\
\hline 比の断面保数 $Z$ & & $3.6880 \mathrm{E}-03 \mathrm{~m}^{4}$ \\
\hline
\end{tabular}

图-4 滆算条件（共通）
計算時間は次のとおりである。

(条件 1)

三角形分布荷重 (分割数50)

(結果 1)

アンカー 5 段

FMR-70 $\mathrm{HX}_{2} 21 \mathrm{sec}$

地層数 7 層

(条件 2)

FMR-60 FD $39 \mathrm{sec}$

集中荷重 1 個

アンカーなし

(結果 2 )

地層数 1 原

FMR $-70 \mathrm{HX}_{2} \quad 8 \mathrm{sec}$ FMR-60 FD $13 \mathrm{sec}$

\section{4. 考 察}

\section{1 外力条件の違いの影響}

外力の分布形態が集中荷重であるか，分布荷重（正確 には分布荷重を多数の集中荷重でおきかえたもの）であ るかによって，杭に生じるたわみ，応力等にどのような 違いが生じるかを調べた。それによると，外力分布形態 の違いの影響は移動層部の杭と不動首中の杭とでは異な る。不動層中の杭に関しては, 詳しい説明は省略するが, 分布荷重に等価な集中荷重が存在して, 不動層中の杭に 与える力学的効果（たわみ，たわみ角，曲げモーメント， せん断力）を分布荷重の場合と全く等しくすることがで きる（表-1の CASE 1 と CASE 4)。一方，移動層部で は，分布荷重と等価な集中荷重は存在せず，同じ全体荷 重を与えたとしても, 集中荷重, 三角形分布荷重, 台形 分布荷重, 長方形分布荷重あるいは一般の分布荷重では 杭に生じる影響は異なる。1 例として, 表-1の条件の場 合で，杭に生じるたわみ，たわみ角，曲げモーメント， せん断力は CASE 1 の集中荷重 1 個の場合を100\%とし て, 三角形分布荷重（CASE 2) では68 69\%，台形 分布荷重（CASE 3）では83 92\%，長方形分布荷重 (CASE 4) では100〜117\%となる。

\section{2 アンカーの段数の影響}

アンカーなしの抑え杭に生じるたわみ，たわみ角，曲 げモーメント，せん断力は大きなものになりがちである。 しかし，アンカーを取り付けると，それらを小さくする ことができる。例をあげると, $48.3 \mathrm{tf}$ の集中荷重が作 用した場合（表-1の CASE 1, 図-5.1）には， $y_{\max }=$ $44.8 \mathrm{~cm}, \theta_{\max }=0.052 \mathrm{rad}, M_{\max }=222.79 \mathrm{tf}, S_{\max }=$ $88.48 \mathrm{tf}$ といら值になる。これに，適当な位置にアンカ 一を取り付けると，上記のケースを $100 \%$ として，アン カー1 段の場合(表-1の CASE 5) $y_{\max }=5.4 \%, \theta_{\max }=$ $19.2 \%, M_{\max }=36.4 \%, S_{\max }=28.4 \%$ 飞， 2 段の場合 (表-1の CASE 6) は, $y_{\max }=9.9 \%, \quad \theta_{\max }=3.8 \%$, $M_{\max }=15.9 \%, S_{\max }=43.8 \%$ に，3段の場合（表-1の CASE 7）は, $y_{\max }=0.2 \%, \theta_{\max }=0.0 \%, M_{\max }=4.2$ $\%, S_{\max }=13.2 \%$ にそれぞれ減少する。ただし，ここで 気をつけないといけないことは，曲げモーメントやせん 断力はアンカーを取り付ける位置によって変化し，それ 


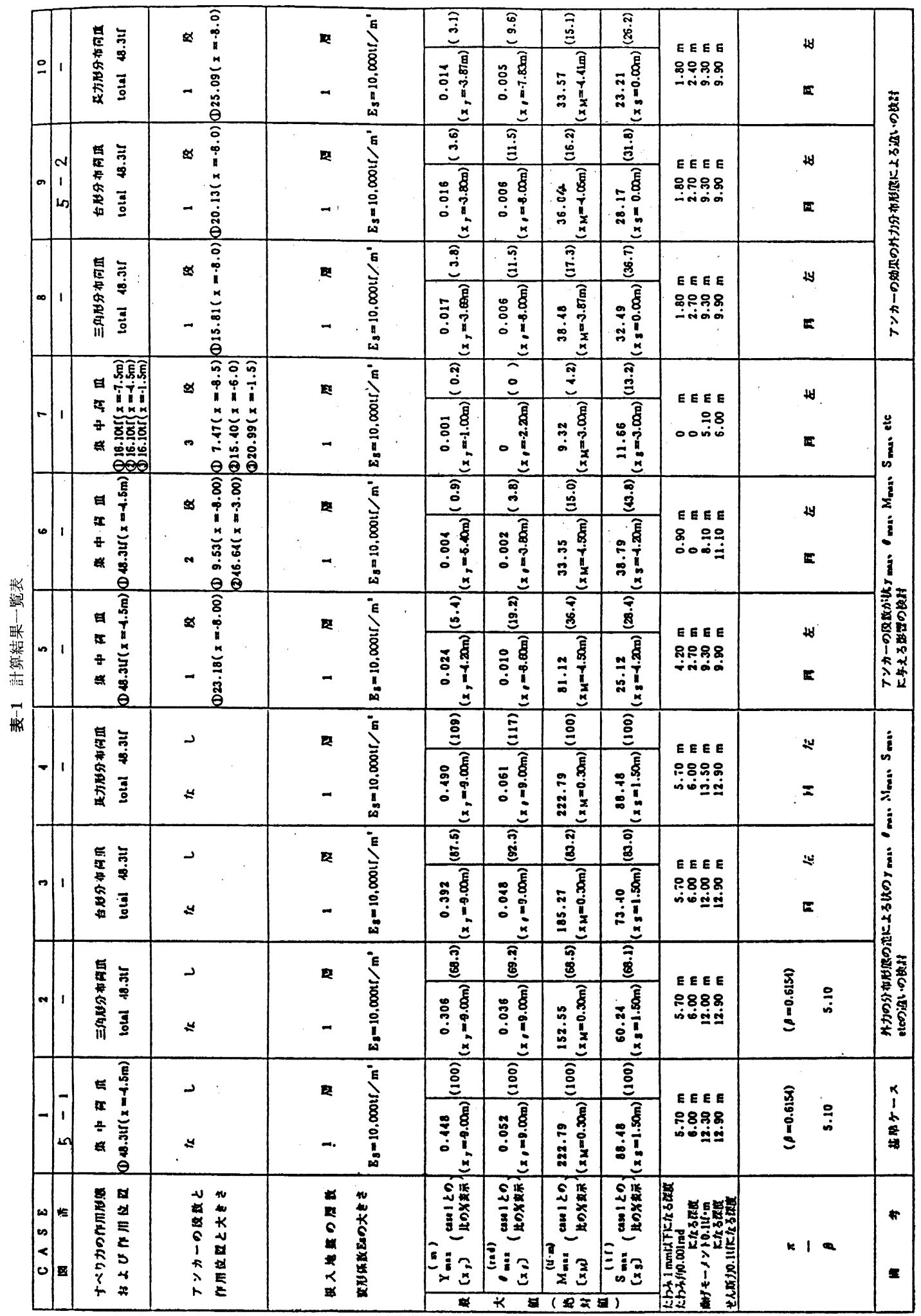




\begin{tabular}{|c|c|c|c|c|c|c|c|c|c|c|}
\hline $\begin{array}{lll}\infty & 1\end{array}$ & 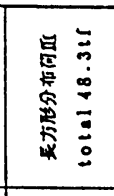 & 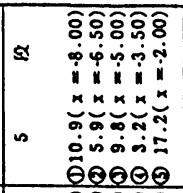 & 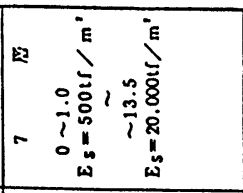 & 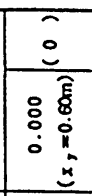 & $\frac{0}{\stackrel{0}{\bar{g}}}$ & 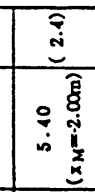 & 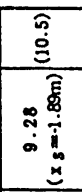 & $\begin{array}{l}\text { E E E E } \\
1180 \\
1180\end{array}$ & H & \\
\hline$\approx 1$ & 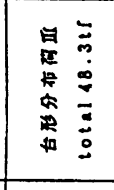 & 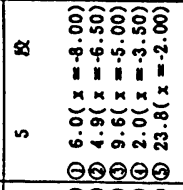 & a & 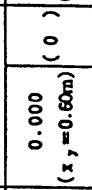 & 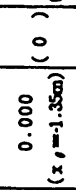 & 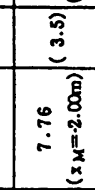 & 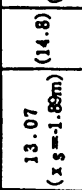 & 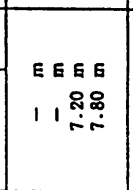 & ty & 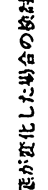 \\
\hline$=\begin{array}{l}+ \\
1 \\
-\infty\end{array}$ & 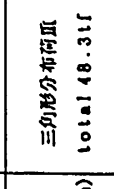 & 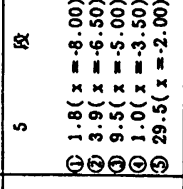 & 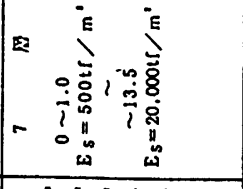 & 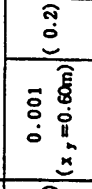 & 這 & 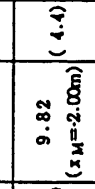 & 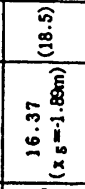 & 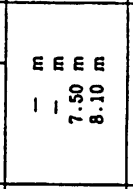 & E & 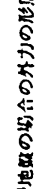 \\
\hline$=1$ & 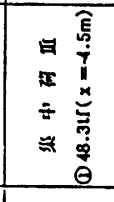 & 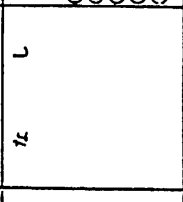 & 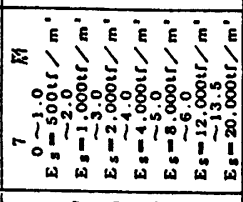 & 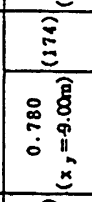 & 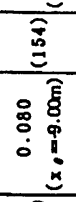 & 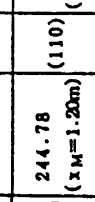 & 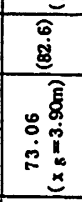 & 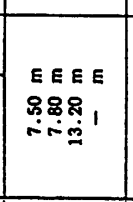 & 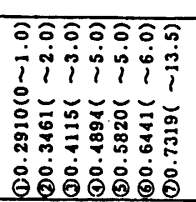 & 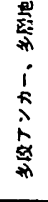 \\
\hline$=\begin{array}{l}m \\
1 \\
4\end{array}$ & 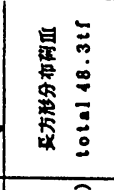 & $\approx$ & 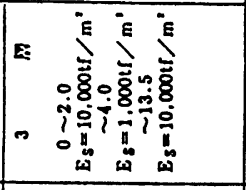 & 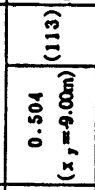 & 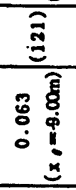 & 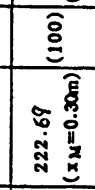 & 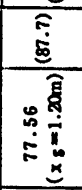 & 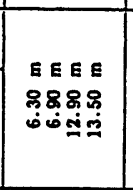 & $\begin{array}{l}H \\
E\end{array}$ & 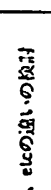 \\
\hline$=1$ & 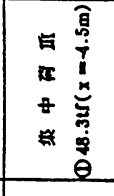 & $\approx$ & 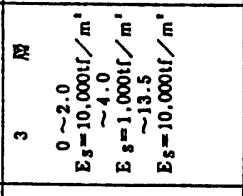 & 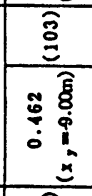 & 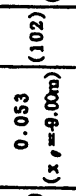 & 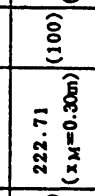 & 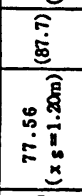 & 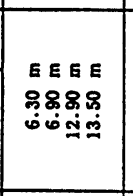 & 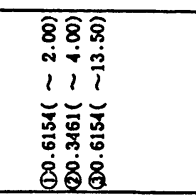 & 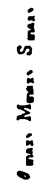 \\
\hline$\approx 1$ & 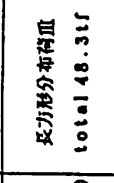 & $\approx$ & 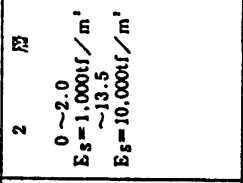 & $\frac{\widehat{\widehat{E}}}{\stackrel{\widehat{E}}{=}}$ & 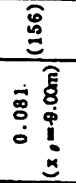 & 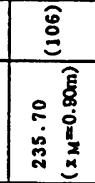 & 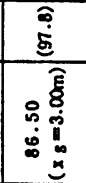 & 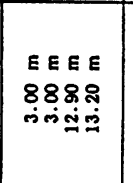 & E & 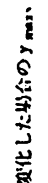 \\
\hline$\Rightarrow 1$ & 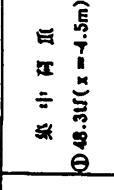 & $\Delta$ & 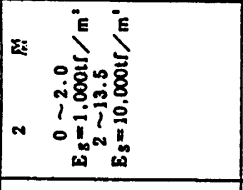 & 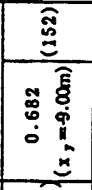 & 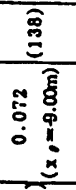 & 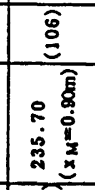 & 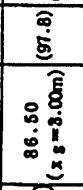 & 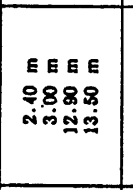 & 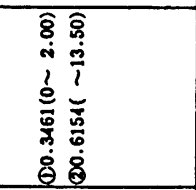 & 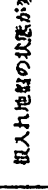 \\
\hline $\left.\mid \begin{array}{ll}\omega & * \\
\infty & \\
< \\
0\end{array}\right]$ & 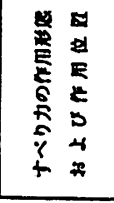 & 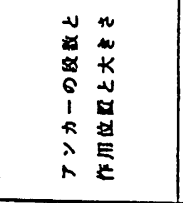 & 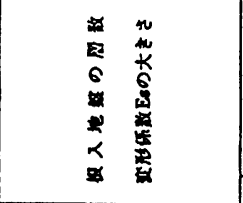 & 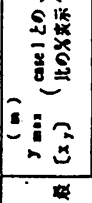 & 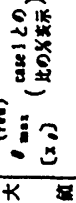 & 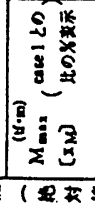 & 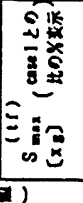 & 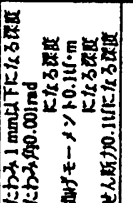 & $a$ & 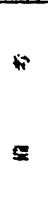 \\
\hline
\end{tabular}




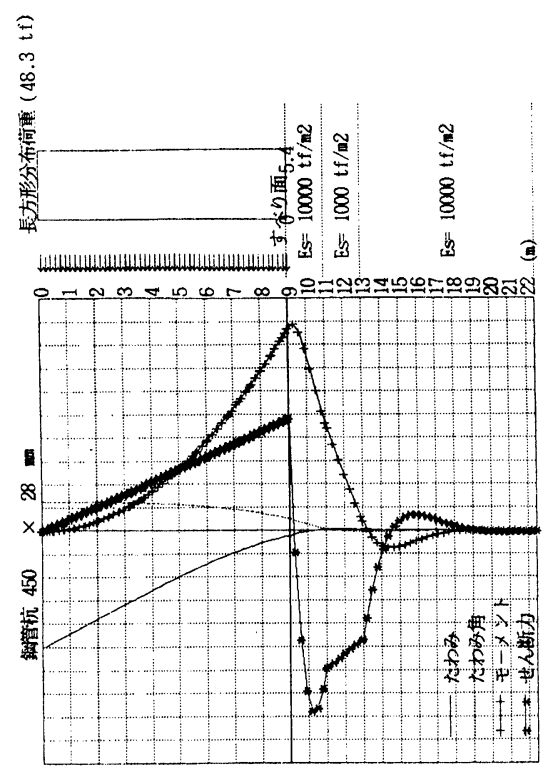

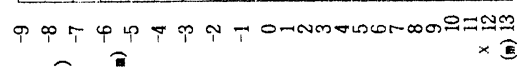

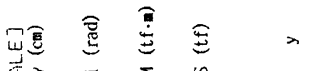

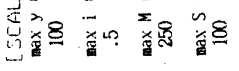

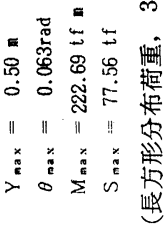

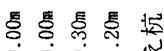
क्षें $\dot{x} \dot{x} \dot{x} \times \ddot{x}$

图 $\underset{\$}{\infty}$

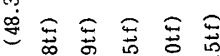

制

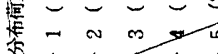

觜

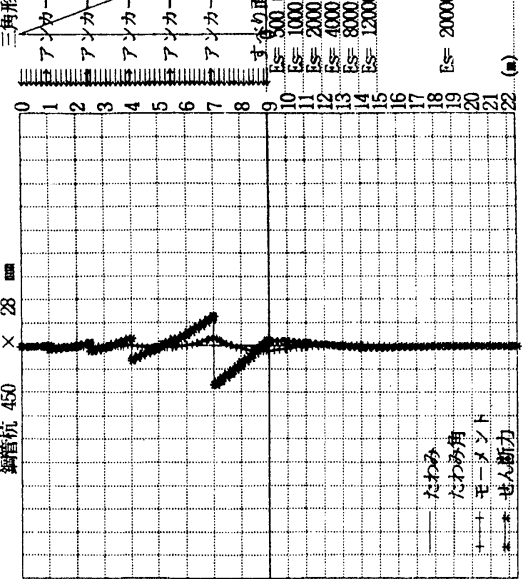

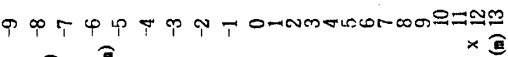

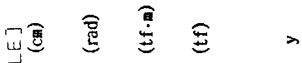

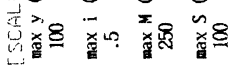

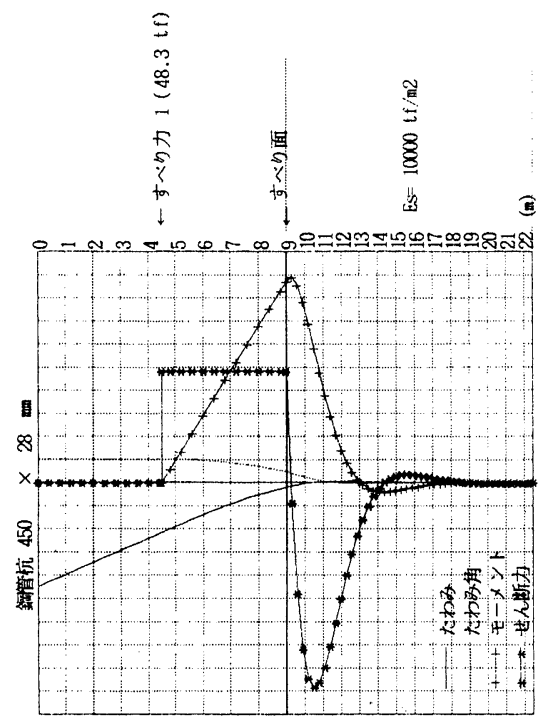

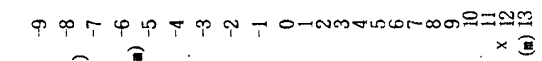
毞要焉焉》。

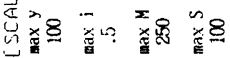
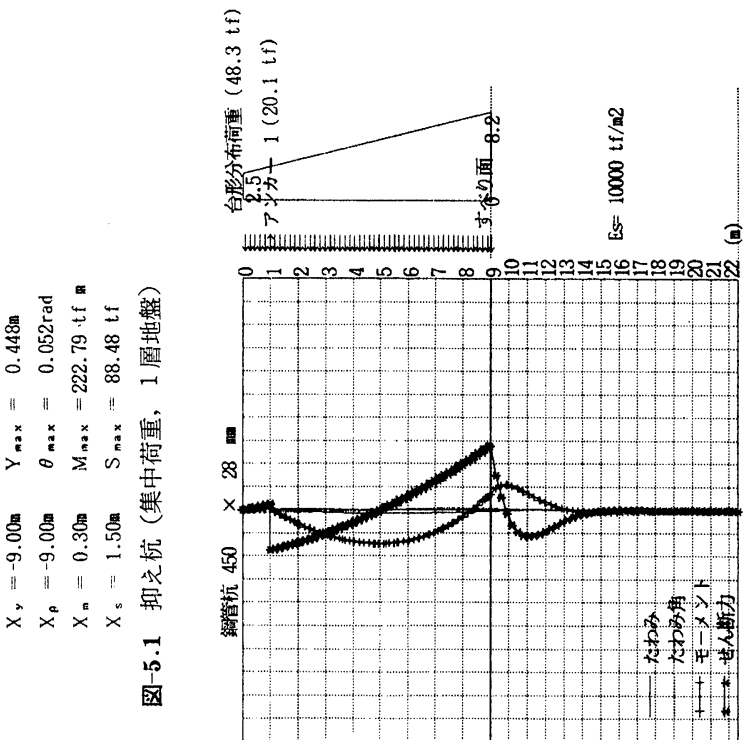

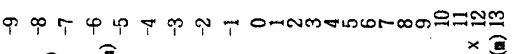

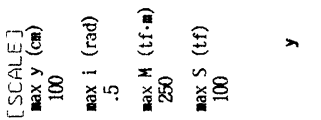
热 ல் $\dot{0} \dot{\varphi}$ " II | | | 11 : 窟 悉 苞 il $\dot{i} \vec{i} \quad \vec{i} R$ $\ddot{x} \dot{x} \dot{x} \dot{x}^{n} \hat{R}$ 芦 
らの最大值は移動層内に生じることもあるといらことで ある。次に，杭の根入れ長に関係する不動層中の杭のた わみ, たわみ佣, 曲げモーメント，世九断力の大きさと 深度の関係については次のようなことが明らかになった。 不動層中で $y=1 \mathrm{~mm}$ 以下, $\theta=0.01 \mathrm{rad}$ 以下, $M=0.1$ $\mathrm{tf} \cdot \mathrm{m}$ 以下， $S=0.1 \mathrm{tf}$ 以下になる深度が，フンカーなし の場合（表-1の CASE 1, 図-1），すべり面から，それぞ れ5.70m, 6.00m, $12.30 \mathrm{~m}, 12.90 \mathrm{~m}$ であったものが, アンカーを取り付けると、1 段の場合（表-1の CASE 5) $4.20 \mathrm{~m}, 2.70 \mathrm{~m}, 9.30 \mathrm{~m}, 9.90 \mathrm{~m}, 2$ 段の場合（表-1の CASE 6) $090 \mathrm{~m}, 0 \mathrm{~m}, 8.10 \mathrm{~m}, 11.10 \mathrm{~m}, 3$ 段の歩合 (表-1の CASE 7), $0 \mathrm{~m}, 0 \mathrm{~m}, 5.10 \mathrm{~m}, 6.00 \mathrm{~m}$ と浅く なってくる。このことは，抑止杭を計画しているとき， すべり面下に軟らかい層があり; 地盤反力がとれない場 合や背後の構造物等の関係で, 根入れ部の反力が大きく なると不都合な場合 アンカーの定着層を確保できるな らば, フンカー付き抑光杭が非常に有効な手段となるこ とを示唆している。

\section{3 多層地盤の影響}

すべり面より下に, 軟らかい層がある場合, 移動層部 でのたわみ，たわみ角は軟らかい層のない場合に比べて， 一般に増加する。 $M_{\max }$ もやや增加するが， $S_{\max }$ は減 少する傾向にある。すべり面に近い部分に軟らかい層が ある場合には，これらの傾向は特に顕著であるが，すべ り面より離れるにしたがって，せん断力を除いて，弱く なる。すべり面下に厚さ $2 \mathrm{~m} の$ 相対的に軟らかい $E_{s}=$ $1000 \mathrm{tf} / \mathrm{m}^{2}$ の地層がある場合（表-1の CASE 11）は, ない場合（表-1 の CASE 1）に比へて $y_{\max }=152 \%$, $\theta_{\max }=138 \%, M_{\max }=106 \%, S_{\max }=97.8 \%$ となる。こ れに対し，すべり面下 $2 \mathrm{~m} \sim 4 \mathrm{~m}$ の $2 \mathrm{~m}$ 区間に $E_{s}=$ $1000 \mathrm{tf} / \mathrm{m}^{2}$ の地層があるとき（表-1の CASE 13）は, $y_{\max }=103 \%, \quad \theta_{\max }=102 \%, \quad M_{\max }=100 \%, \quad S_{\max }=$ 87.7\%となる。また，すべり面下に軟らかい地層が厚く 存在すればするほど， $M_{\max }, S_{\max }$ が生じる位置が下 方に移る傾向にある。

表-1の CASE 1 では $M_{\max } ， S_{\max }$ が生じる位置はす ベり面下 $0.30 \mathrm{~m}, 1.50 \mathrm{~m}$ であったものが, 表-1の CASE 11 では0.90m，3.00m となり表-1の CASE 15 では1. 20 $\mathrm{m}, 3.90 \mathrm{~m}$ となっている。

\section{5. まとめ}

(1) 多層地盤中の抑光杭に，多段のアンカーを取り付 けた場合の杭のたわみ，たわみ角，曲げモーメント，せ ん断力を計算する式を導出した。この式を用いれば，外 カとして：集中荷重ばかりでなく，任意の形態の分布荷 重も計算できる。

（2）導出した計算式をパソコン用にプログラミングし て外力条件, アンカー段数, 地盤条件の違いが, 杭のた
わみ，たわみ角，曲げモーメント，せん断打に与える影 響を系統的に調べた。

（3）集中荷重と分布荷重の違いに関しては，次のこと がいえる。

不動層中の杭については，分布荷重（あるいは多数の 集中荷重）と全く力学的効果（たわみ，たわみ角，曲げ モーメント，せん断力の大きさ）が等しくなるように, 等価な集中荷重の大きさと作用位置を決定することがで きる。一方, 移動層部では, 分布荷重に等価な集中荷重 は存在せず, 不動境中に等しい力学的効果を与える等価 集中荷重と比べて，たわみ，たわみ角は分布荷重の方が 大きくなる傾向にあり，また，曲げモーメント，せん断 力の分布形態は, 集中荷重, 分布荷重で異なってくる。

三角形分布荷重, 上底が下底よりも短い台形分布荷重, 長方形分布荷重では, 他の条件が同じであれば, この順 に杭の $y_{\max }, \theta_{\max }, M_{\max }, S_{\max }$ は大きくなる。

（4）杭にアンカーを取り付けることによって，アンカ 一なしの場合に比べて, 著しく杭に生じるたわみ，たわ み角, 曲げモーメント，せん断力を小さくすることがで きるばかりか，根入れ長も短くすることができる。アン カーの負担力は，取り付け位置のたわみを0にするよら に決定するとよい。その場合, 外力の分布形態, 取り付け 位置によって，アンカーの負担力は複雑に变わってくる。

（5）すべり面より下に軟らかい層があると，たわみ， たわみ角, 曲げモーメントは増加し，せん断力は減少す る傾向にある。また軟らかい, 層が厚ければ, 最大曲げモ ーメント，最大せん断力を与える位置も下方に移動する 傾向にある。

（6）ここに述べた方法を市販のパソコンを用いて実行 すると，三角形分布荷重， 7 㬝地盤，5段アンカーとい ら条件で, MS-DOS 上の BASIC 言語を用いて $21 \mathrm{sec}$ (32ビット機, クロック数 $20 \mathrm{MHZ}$ ) 及び $39 \mathrm{sec}$ (16ビ ット機, クロック数 12MHZ) であったので十分実用的 なものと言える。

\section{謝 辞}

本論文については, 建設省土木研究所地すべり研究室 中村室長に適切な批評をしていただきました。心より， 拈礼申し上げます。また，日本基礎技術(株)の調查・技 術・工事の各分野で協力願った関係各位に対しても謝意 を表します。

\section{参考文献}

1）中村浩之・土尾 智：地すべり変位を考慮した地すべり抑 止杭の解析, 地すべり, Vol.24, No.2, pp.17 25, 1987

2) 栄藤 修. 森崎 充・中野 明・福的久弥・後藤社二：杭 頭アンカー付抑止杭候関する・考察, 第27回地すべり学会 研究発表会講演集, pp.194 197，1988

3）横山幸満：ーパーソナル・コンピュータのための-荷重関数 法による梁の力学, 山海堂, 1987

（原稿受理日 平成 2 年 1 月 25 日） 